\title{
Electron microscopical investigations on starvation-induced liver pathology in flounders Platichthys flesus
}

\author{
H. Segner ${ }^{1}$ and H. Möller ${ }^{2}$ \\ 1 Zoologisches Institut I der Universität, Im Neuenheimer Feld 230, D-6900 Heidelberg, Federal Republic of Germany \\ 2 Institut für Meereskunde an der Universität, Düsternbrooker Weg 20, D-2300 Kiel, Federal Republic of Germany
}

\begin{abstract}
Ultrastructure of fish liver is correlated to the quality of the environment to which the fish is exposed. We report here effects of starvation on the liver of juvenile flounders Platichthys flesus L., compared to livers of wellnourished con-specifics. Characteristic changes are decrease of stored products, reduction of endoplasmic reticulum, increased numbers of lysosomes and macrophages, proliferation of collagenous fibres, dissolving of cell junctions and associated parenchymal disarray. All alterations proved to be reversible, providing a $60 \mathrm{~d}$ period of starvation was followed by $5 \mathrm{~d}$ of re-feeding.
\end{abstract}

The liver cell ultrastructure of teleosts responds very sensitively to environmental changes, e.g. in temperature, season, feeding conditions or presence of various chemicals in the water (for literature see Storch and Juario, 1983). Attempts have been made to use this responsiveness as an indicator for aquatic pollution effects (Pierce et al., 1978, 1980; Peters, 1981; Haensley et al., 1982).

Recently, flounder Platichthys flesus from the polluted Elbe River have become the subject of several pathological studies (Köhler and Hölzel, 1980; Wichowski, 1983; Anders, 1984; Möller, 1984a). Pollution, as well as various natural conditions, have been suspected to be responsible for locally high disease rates of flounder in this area. Future studies intend to integrate the histological conditions of flounder liver as additional item in surveys. Suspecting that nutritional condition is one of the major factors regulating disease rates (Möller, 1984b), the present study examines under laboratory conditions the 'normal' state of flounder liver as well as effects of starvation and re-feeding.

Experiments were conducted with 17 juvenile flounders, 10 to $12 \mathrm{~cm}$ long, caught in January 1983 in Kiel Bight, western Baltic Sea. The flounders were acclimatized to 14 to $17^{\circ} \mathrm{C}$ and 15 to $18 \% \mathrm{~S}$ for $1 \mathrm{mo}$ in the laboratory of the 'Institut für Meereskunde', Kiel. During this time they were fed a mixture of minced mussel meat (Mytilus edulis), living amphipods and isopods. After this acclimatization period one group of 5 individuals continued to receive food daily, whereas a second group of 12 individuals was starved for $60 \mathrm{~d}$. Feeding was continued after $60 \mathrm{~d}$ with 3 individuals each from the second group for $6 \mathrm{~h}, 24 \mathrm{~h}$, and $5 \mathrm{~d}$ ad libitum. No signs of disease were detected during acclimatization or experimental period.

For electron microscopy, small portions of the caudal part of the liver were immersed in cold $3.5 \%$ glutaraldehyde solution at $\mathrm{pH} 7.1$ for $2 \mathrm{~h}$. After rinsing the tissues several times in cold Soerensen's buffer, these were post-fixed in $1 \%$ osmium tetroxide solution for $2 \mathrm{~h}$. The tissues were then dehydrated in a series of graded ethanol, placed into propylene oxide and embedded in araldite. Ultrathin sections were stained with uranyl acetate and lead citrate prior to examination under the electron microscopy Zeiss EM 9 S-2.

Liver ultrastructure of fed specimens (Fig. 1). The large liver cells exhibit a regular outline. They are dominated by storage deposites. Large numbers of glycogen rosettes are present in all hepatocytes, whereas the amount of lipid is variable in individuals as well as in different regions of a given liver. Fat inclusions can attain the size of nuclei. Areas free of lipids were not found.

Köhler and Hölzel (1980) considered a pronounced lipoid vacuolization of flounder liver from the Elbe to be pollution-associated. However, as documented by Welsch and Storch (1973), Pierce et al. $(1978,1980)$ and our results, storage of lipid in flatfish livers is a normal process and generally not considered to be pathological as it is in mammals (David, 1964).

The large, centrally located nucleus has a slightly lobulated outline; it possesses a prominent nucleolus and dense clumps of heterochromatin. Mitochondria are of crista-type and have a moderately dense matrix. They are always associated with ER-cistemae and dis- 


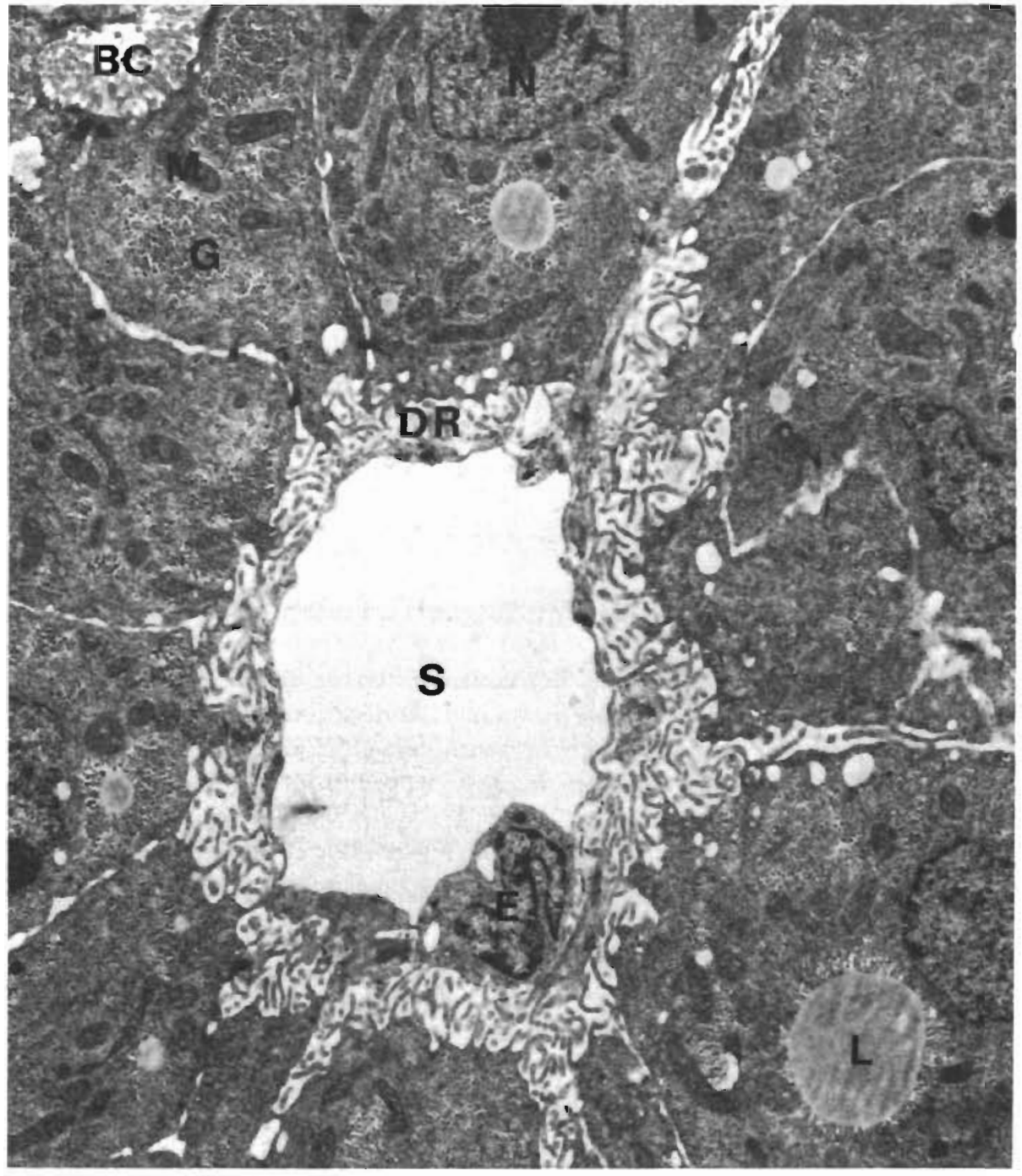

Fig. 1. Platichthys flesus. Liver of fed specimen. Large hepatocytes are arranged radially around the sinusoidal blood space. They contain glycogen and lipid. $8190 \times$. Abbreviations see legend to Fig. 2 persed throughout the cytoplasm. The ribosome-studded endoplasmic reticulum is concentrated around the nucleus and at the periphery of the cell. Particularly at the sinusoidal pole of the hepatocyte, the peripheral ER can develop to extended layers. Frequently, dark granules are located at their sides. Golgi bodies are rarely found. A few lysosomes can be observed in a peribiliar position.

The space of Disse of the liver of flounder possesses a moderate amount of collagenous fibres. The bile canaliculi are surrounded by 2 to 4 hepatocytes. Cell junctions are very numerous.

Liver ultrastructure of starved specimens (Fig. 2). Five outstanding alterations were found in the livers of starved flounder:

(1) Decrease in cell size due to a drastic loss of glycogen and lipid. Some glycogen rosettes remain, lipid can no longer be found. While the nucleus is not clearly affected, its relative share in cell volume is strongly increased. Nucleoli are frequently absent.
Mitochondria are more spherical, the matrix electrondense, and the cristae shortened.

Although a decrease of stored products seems to be a general feature of hepatocytes of starved animals (Langer, 1978; Love, 1980; Storch and Juario, 1983; Segner, 1984), exceptions have been found in certain mammals (David, 1961), and in Salmo gairdneri and Leuciscus idus melanotus (Segner, unpubl.).

(2) Reduction of endoplasmic reticulum. The network of ER membranes mediates intracellular compartmentation and communication. The lose of ER with starvation indicates severe disturbances of cell function and metabolism. Similar observations have been made by Gas and Serfaty (1972), Storch and Juario (1983) and Segner (1984) when studying other starved teleost species.

(3) Enhanced numbers of lysosomes and macrophages. The large lysosomes of homogenous dark matrix are no longer restricted to the peribiliar region. Remarkably high numbers of macrophages, often 
arranged in clusters, can be observed in the blood spaces.

An increase in number and size of lysosomes with starvation was reported for teleosts (Langer, 1978; Storch and Juario, 1983) as well as for mammals (David, 1964). Macrophage centers appear to be normal constituents of liver cells. They are activated in diseased (Roberts, 1975) and starved (Aguis, 1981) fish. Haensly et al. (1982) found high activity in the liver of plaice as a long-term effect of a crude oil spill. Therefore, augmented numbers of macrophages in fish liver cells seem to be a reliable indicator for effects of adverse environmental conditions.

(4) Parenchymal disarray. The parenchymal structure is disorganized and in many cases the endothelial lining of the sinusoids is ruptured. Necrotic areas, however, are rare. Cell junctions often are dissolved, except the junctional complexes surrounding bile canaliculi. This finding expresses metabolic disfunction and disturbed communication at the tissue level. Its significance must be underlined because of the intensive development of junctional complexes in the livers of fed flounder

(5) Increased deposition of collagenous fibres. The microvilli in the space of Disse can be replaced by abundant collagenous fibres. Similar observations have been made in numerous injured livers in mammals (David, 1964).

Liver ultrastructure after re-feeding. After $6 \mathrm{~h}$ of refeeding, no distinct alterations compared to starved specimens occur, except numerous optically empty vesicles along the cell periphery.

One day after the start of re-feeding, a limited enlargement of the hepatocytes occurs. Cells are no longer isolated but in close contact. The vesicles at the cell periphery still exist. Whereas changes in nuclear morphology are not present, the mitochondria exhibit a light matrix and some newly built, but irregularly distributed ER cisternae can be detected. Lysosomes are still numerous. Small numbers of glycogen rosettes are deposited. Intracellular compartimentation is not yet reorganized. Concerning the parenchymal organi-
Fig. 2. Platichthys flesus. Liver of starved specimen. Parenchymal disarray, decrease of stored products and increase of collagenous fibres and lysosomes are obvious. $8800 \times$. Abbreviations for Fig. 1 and 2: $B C=$ bile canaliculus; $\mathrm{DR}=$ space of Disse; $E=$ endothelial cell; $F=$ collagenous fibres; $\mathrm{G}=$ glycogen; $\mathrm{L}=$ lipid $_{\mathrm{L}} \mathrm{LY}=$ lysosome $\mathrm{M}=$ mitochondrium; $\mathrm{N}=$ nuc leus; $\mathrm{S}=$ sinusoid

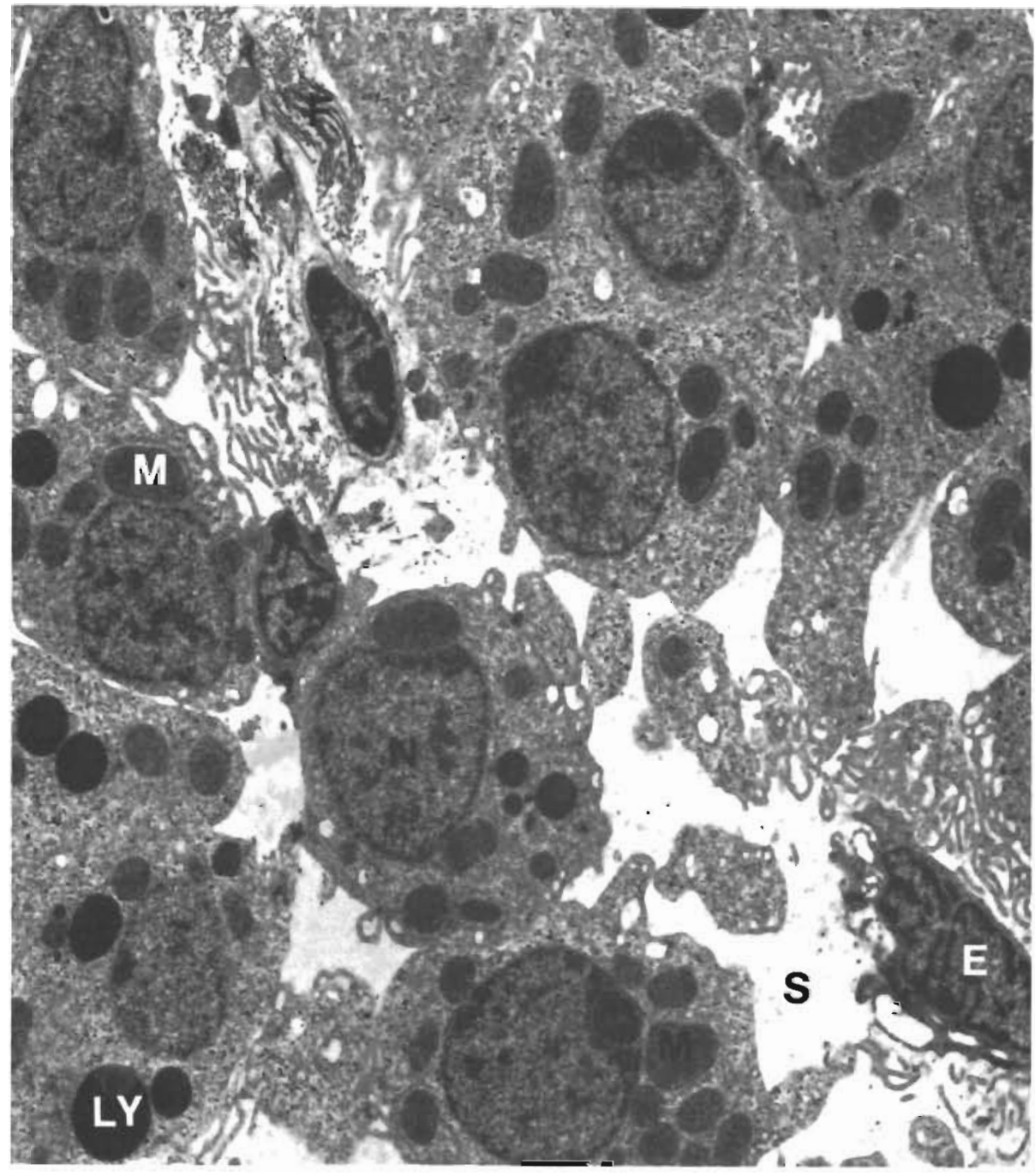


zation, a partial restoration of perisinusoidal spaces occurs. The amount of collagenous fibres is not reduced, the number of macrophages only partially.

After $5 \mathrm{~d}$ of re-feeding, the subcellular and parenchymal organization is still poorly developed, but liver cells are very similar to those of fed specimens. The storage products - glycogen and lipid - are regenerated. It can be concluded that re-feeding with adequate food results in a restoration of flounder liver structure within only a short period of time.

The easily recognizable effects of starvation on flounder liver ultrastructure will be of great diagnostical significance during future field surveys on fish diseases in the lower Elbe River, where locally high disease rates seem to be favoured by bad nutritional conditions of local fish populations (Möller, 1984b).

\section{LITERATURE CITED}

Agius, C. (1981). The effects of splenectomy and subsequent starvation on the storage of haemosiderin by the melanomacrophages of rainbow trout Salmo gairdneri Richardson. J. Fish. Biol. 18: 41-44

Anders, K. (1984). Die Lymphocystis-Krankheit der Fische. Verlag Möller, Kiel, in press

David, H. (1961). Die Leber bei Nahrungsmangel und Mangelernährung. Akademie Verlag, Berlin

David, H. (1964). Submikroskopische Ortho- und Pathomorphologie der Leber. Akademie Verlag, Berlin

Gas, N., Serfaty, A. (1972). Cytophysiologie du foie de carpe (Cyprinus carpio L.). Modifications ultrastructurales consécutives au maintien dans des conditions de jeûne hivernel. J. Physiol., Paris 64: 57-67

Haensly, W. E., Neff, J. M., Sharp, J. R., Morris, A. C., Begood, M. F., Boem, P. D. (1982). Histopathology of Pleuronectes platessa L. from Aber Wrac'h and Aber Benoit, Brittany, France: long-term effects of the Amoco Cadiz crude oil spill. J. Fish Dis. 5: 365-391

Köhler, A., Hölzel, F. (1980). Investigation on health condi- tions of flounder and smelt in the Elbe estuary. Helgoländer Meeresunters. 33: 401-414

Langer, M. (1978). Wirkung endogener und exogener Hungerzustände auf die Hepatocytenstruktur des Maulbrüters Haplochromis burtoni (Cichlidae: Teleostei). Zool. Jb. (Anat. Ontogenie Tiere) 100: 399-432

Love, M. R. (1980). Chemical biology of fishes. Academic Press, New York

Möller, H. (1984a). Dynamics of fish diseases in the lower Elbe River. Helgoländer Meeresunters. 37: 389-413

Möller, H. (1984b). Daten zur Biologie der Elbfische. H. Möller, Kiel

Peters, N. (1981). Fischkrankheiten und Gewässerbelastung im Küstenbereich. Verh. dt. zool. Ges. 1981: 16-30

Pierce, K. V., McCain, B. B., Wellings, S. R. (1978). Pathology of hepatomas and other liver abnormalities in English sole (Parophrys vetulus) from the Duwamish River estuary, Seattle, Washington, J. natn. Cancer Inst. 60: 1445-1453

Pierce, K. V., McCain, B. B., Wellings, S. R. (1980). Histopathology of abnormal livers and other organs of starry flounder Platichthys stellatus (Pallas) from the estuary of the Duwamish River, Seattle, Washington, U. S. A. J. Fish Dis. 3: 81-91

Roberts, R. J. (1975). Melanin-containing cells of teleost fish and their relation to disease. In: Ribelin, W. E., Migaki, G. (ed.) The pathology of fishes. University of Wicsonsin Press, Madison, p. 399-428

Segner, H. (1984). Influence of starvation and refeeding with different diets on the hepatocyte ultrastructure of juvenile Siganus guttatus Bloch (Siganidae: Teleostei). Zool. Anz., in press

Storch, V., Juario, J. V. (1983). The effect of starvation and subsequent refeeding on the hepatocytes of Chanos chanos (Forsskal) fingerlings and fry. J. Fish Biol. 23: 95 -103

Welsch, V. N., Storch, V. (1973). Enzyme histochemical and ultrastructural observations on the liver of teleost fishes. Arch. histol. jap. 36: 21-37

Wichowski, F. (1983). Parasitologische Untersuchungen an Elbfischen. Diplomarbeit, Institut für Meereskunde, Universität Kiel

Accepted for printing on May 25, 1984 